\title{
Lovastatin Inhibits $\alpha$-Farnesene Synthesis without Affecting Ethylene Production during Fruit Ripening in 'Golden Supreme' Apples
}

\author{
Zhiguo Ju and Eric A. Curry \\ U.S. Department of Agriculture, Agricultural Research Service, Tree Fruit Research Laboratory, 1104 \\ North Western Avenue, Wenatchee, WA 98801
}

\begin{abstract}
AdDitional INDEX wORDs. hydroxymethylglutaryl coenzyme-A reductase, ethephon, mevinolin, scald, Malus sylvestris var. domestica
\end{abstract}

\begin{abstract}
Lovastatin is a specific hydroxymethylglutaryl coenzyme-A reductase inhibitor in animals and as such, is a potent cholesterol lowering pharmaceutical for human use. Because it has also been shown to inhibit $\alpha$-farnesene in certain plants, we investigated its effects on ethylene and $\alpha$-farnesene biosynthesis, volatile production, and fruit color during ripening in 'Golden Supreme' apples [Malus sylvestris (L.) Mill. var. domestica (Borkh.) Mansf.]. Immediately after harvest, fruit were dipped in Lovastatin solution for 2 min, allowed to dry, and stored in the dark at $20{ }^{\circ} \mathrm{C}$ for 30 days. Internal ethylene at harvest was low $\left(<0.1 \mathrm{~mL} \cdot \mathrm{L}^{-1}\right)$ and $\alpha$-farnesene was undetectable. Both internal ethylene and $\alpha$-farnesene increased in nontreated fruit during 30 days storage. Prestorage Lovastatin treatment did not affect ethylene synthesis, but at 1.25 or $2.5 \mathrm{mmol} \cdot \mathrm{L}^{-1}$ nearly eliminated $\alpha$-farnesene production. At $0.25 \mathrm{mmol} \cdot \mathrm{L}^{-1}$, Lovastatin delayed the increase in $\alpha$-farnesene production about 12 days and reduced total $\alpha$-farnesene production by the end of storage compared with controls. When applied to nontreated preclimacteric fruit, ethephon at $1.4 \mathrm{mmol} \cdot \mathrm{L}^{-1}$ increased both internal ethylene concentration and $\alpha$-farnesene production. In Lovastatin-treated preclimacteric fruit, however, ethephon increased internal ethylene concentration without promoting $\alpha$-farnesene synthesis. In another trial, after 30 days storage at $0{ }^{\circ} \mathrm{C}$, fruit were treated with $1.25 \mathrm{mmol} \cdot \mathrm{L}^{-1} \mathrm{Lovastatin}$ and stored at $20{ }^{\circ} \mathrm{C}$ with air circulation for 20 days. These fruit accumulated similar amounts of ethylene as nontreated controls, but $\alpha$-farnesene production decreased rapidly and was not detectable after 5 days. Treating with ethephon at $1.4 \mathrm{mmol} \cdot \mathrm{L}^{-1}$ increased $\alpha$-farnesene production in control fruit but not in Lovastatin-treated fruit. Lovastatin treatment did not affect the change in fruit color. Chemical names used: [1S-[ $\left.\left.1 \alpha\left(R^{\circ}\right), 3 \alpha, 7 \beta, 8 \beta\left(2 S^{\circ}, 4 S^{\circ}\right), 8 a b\right]\right]-1,2,3,7,8,8 \alpha-h e x a h y d r o-3,7-d i m e t h y l-8$-[2-(tetrahydro-4-hydroxy6-oxo-2H-pyran-2-yl)ethyl]-1-naphthaienyl 2-methylbutanoate (Lovastatin); 2-chloroethylphosphonic acid (ethephon).
\end{abstract}

A positive correlation between $\alpha$-farnesene and scald development in apples is well documented in the literature (Ingle and D'Souza, 1989; Whitaker et al., 1997). However, the role of $\alpha$ farnesene in scald development has never been clear. The concentration of $\alpha$-farnesene, an acyclic sesquiterpene synthesized in young apple fruit, decreases gradually during the fruit enlargement period (Sutherland et al., 1977). It is undetectable in preclimacteric fruit at harvest but increases during fruit ripening and during cold storage (Huelin and Coggiola, 1970a, 1970b; Huelin and Murray, 1966; Meigh andFilmer, 1969; Murray etal., 1964). This compound undergoes autooxidation easily in the presence of oxygen, forming free radicals and conjugated trienes (Anet, 1969; Rowan et al., 1995; Whitaker et al., 1997). Accumulation of $\alpha$-farnesene and its oxidation products correlates well with scald development, and application of antioxidants like diphenylamine or ethoxyquin controls the disorder satisfactorily (Ingle and D'Souza, 1989). Curiously, certain practices such as preharvest ethephon treatment, which stimulate $\alpha$-farnesene production, also reduce scald development (Barden and Bramlage, 1994; Curry, 1994; Du and Bramlage, 1994; Watkins et al., 1993). Therefore, the role of $\alpha$-farnesene in affecting scald development needs to be examined further.

Received for publication 8 Mar. 1999. Accepted for publication 10 Oct. 1999. This research was supported by the Washington Fruit Tree Research Commission. The authors are grateful to Carol Duplaga, Carol Pavelko, Doris Frederick, Dave Buchanan, and Rodney Roberts from the USDA-ARS, Tree Fruit Research Laboratory, Wenatchee, Wash., for technical support. Many thanks to Robert Hagenmaier from the USDA-ARS Quality Improvement in Citrus and Subtropical Products Laboratory, Winter Haven, Fla., for providing suggestions on microemulsion formulae. The cost of publishing this paper was defrayed in part by the payment of page charges. Under postal regulations, this paper therefore must be hereby marked advertisement solely to indicate this fact.
The relationship between $\alpha$-farnesene and scald development in apples may be pursued from different directions. One is to apply $\alpha$-farnesene or its oxidation product directly to fruit and to evaluate its effects on scald development. This has been tried and results are inconclusive. While 6-methyl-5-heptene-2-one, a purported $\alpha$-farnesene oxidation product, induces scald-like symptoms when applied to fruit (Song and Beaudry, 1996), applying $\alpha$-farnesene directly to fruit does not induce scald (Huelin and Coggiola, 1970b) and even reduces scald development in apples and pears (Curry, 1999).

Another approach is to inhibit $\alpha$-farnesene synthesis and examine the impact on scald development. Ju and Bramlage (unpublished data) found that combining a preharvest treatment of aminoethoxyvinylglycine (AVG) with low-ethylene storage (without other ethylene sources except the AVG-treated fruit) held $\alpha$-farnesene concentration to undetectable levels, and scald was controlled completely. However, internal ethylene was also reduced to a very low level $\left(<1 \mathrm{~mL} \cdot \mathrm{L}^{-1}\right)$ in that experiment. When AVG-treated fruit were stored in a commercial storage room where ambient ethylene was high, fruit accumulated $\alpha$-farnesene and developed scald. Since ethylene and $\alpha$-farnesene synthesis appear to be closely associated (Watkins et al., 1993), it is not clear whether scald inhibition is due to inhibited $\alpha$-farnesene synthesis or due to inhibited ethylene production. Moreover, these AVG-treated fruit often have poor flavor because of the inhibited fruit ripening (Ju and Bramlage, unpublished data) and reduced volatile production (Bangerth and Streif, 1987; HalderDoll and Bangerth, 1987). In view of these data, the next logical approach to clarify the relation between $\alpha$-farnesene and scald would necessitate a treatment that would inhibit $\alpha$-farnesene 
synthesis without interfering with ethylene production or action.

In apples, $\alpha$-farnesene is synthesized through the isoprenoid pathway (Rupasinghe et al., 1998) with hydroxymethylglutaryl coenzyme-A reductase (HMGR) being one of the key enzymes in this pathway (Bach, 1995; Chappell, 1995). Mevinolin (Alberts et al., 1980), now called Lovastatin (Merck Research Laboratory, Rahway, N.J.), is a competitive inhibitor of HMGR and a potent cholesterol-lowering pharmaceutical in animals. It also effectively inhibits isoprenoid synthesis in plants such as radish seedlings (Raphanus sativus L. 'Saxa Treib') (Bach and Lichtenthaler, 1983). In tobacco (Nicotiana tabacum L.) cellsuspension cultures, inhibition of sesquiterpenoids by mevinolin was dose-dependent (Chapell and Nable, 1987). Its effects on $\alpha$ farnesene synthesis in apples, however, and on ethylene biosynthesis in plants have not been studied. The objective of this study was to investigate the effects of Lovastatin treatment on ethylene and $\alpha$-farnesene biosynthesis, volatile production, and fruit color during fruit ripening in 'Golden Supreme' apples.

\section{Materials and Methods}

Lovastatin FORMULATION. Lovastatin was a gift from Merck Research Laboratory, Rahway, N.J. Two formulations were used in this experiment. The first formulation was an oil solution, prepared by dissolving Lovastatin in chloroform and then diluting with stripped corn oil (Fisher, Pittsburgh, Pa.). Lovastatin concentrations tested were $0,0.25,1.25$, and $2.50 \mathrm{mmol} \cdot \mathrm{L}^{-1}$. The second formulation was prepared by dissolving $8.0 \mathrm{~g}$ Lovastatin in $120 \mathrm{~g}$ monoglyceride of oleic acid and then mixing with $180 \mathrm{~g}$ Tween 60 and $600 \mathrm{~mL}$ hot water, thus forming a microemulsion of $22 \mathrm{mmol} \cdot \mathrm{L}^{-1}$ Lovastatin, which was transparent, light yellow, and stable at room temperature. Lovastatin concentrations used in this experiment $\left(0,0.25,0.63\right.$, and $\left.1.25 \mathrm{mmol} \cdot \mathrm{L}^{-1}\right)$ were obtained by diluting the microemulsion with water.

Fruit treatments. 'Golden Supreme' apples were harvested on 20 Aug. 1998 and stored immediately at $0{ }^{\circ} \mathrm{C}$. After $10 \mathrm{~d}$ storage, half of the fruit were removed from storage, warmed to $25^{\circ} \mathrm{C}$, and wiped with cheesecloth dipped in oil containing Lovastatin. Each fruit received $\approx 0.4 \mathrm{~mL}$ of solution. A separate oil treatment without Lovastatin was also included to serve as a control. Another set of fruit was dipped in the Lovastatin emulsion for $2 \mathrm{~min}$, while an emulsion without Lovastatin served as a control. After drying at $20^{\circ} \mathrm{C}$ overnight, half of the fruit from each of the treatments were dipped in a solution of ethephon at 1.4 $\mathrm{mmol} \cdot \mathrm{L}^{-1}$ for $2 \mathrm{~min}$. Each treatment was replicated three times with 80 fruit in each replication. Treated and control fruit were placed in cardboard boxes and stored at $20^{\circ} \mathrm{C}$. Internal ethylene and $\alpha$-farnesene were measured every $6 \mathrm{~d}$ for $30 \mathrm{~d}$. Then, 10 of the remaining fruit were used for external color measurements with a colorimeter (DP-301; Minolta, Osaka, Japan), taking three readings per fruit and reporting the CIELAB values a* and $b^{*}$ as chroma and hue angle (McGuire, 1992).

In a separate experiment, 200 fruit held at $0{ }^{\circ} \mathrm{C}$ for $30 \mathrm{~d}$ were removed from storage. Half of the fruit were dipped in an emulsion of Lovastatin at $1.25 \mathrm{mmol} \cdot \mathrm{L}^{-1}$ for $2 \mathrm{~min}$. After drying at $20{ }^{\circ} \mathrm{C}, 50$ Lovastatin-treated and 50 nontreated fruit were dipped in ethephon at $1.4 \mathrm{mmol} \cdot \mathrm{L}^{-1}$ for $2 \mathrm{~min}$. Thus, the experiment included the following treatments: ethephon, Lovastatin, Lovastatin plus ethephon, and a control. Fruit from all treatments were placed on paper trays, arranged in a single layer on tables, and stored in a room with air circulation $\left(33.5 \mathrm{~m} \cdot \mathrm{min}^{-1}\right)$ at $20^{\circ} \mathrm{C}$. Ethylene and $\alpha$-farnesene were measured every $5 \mathrm{~d}$ for $20 \mathrm{~d}$ using the methods described below.

$\alpha$-FARNESENE MEASUREMENT. Gas chromatography-mass spectrometry (GS-MS) with a solid-phase microextraction (SPME) method (Paliyath et al., 1997) with modification was used to measure $\alpha$-farnesene. Five fruit from each replication were placed in 4-L glass jars at $20^{\circ} \mathrm{C}$. The jars were connected to a flow-through system with a flow rate of $50 \mathrm{~mL} \cdot \mathrm{min}^{-1}$. After $2 \mathrm{~h}$ equilibrium, a $100 \mathrm{~mm}$ polydimethylsiloxane (PDMS) probe (Supelco, Bellefonte, Pa.) was introduced into each jar and allowed to adsorb volatiles for $10 \mathrm{~min}$. The probe was inserted immediately into the injection port of a gas chromatograph (HP 5890; Hewlett Packard, San Fernando, Calif.). Adsorbed volatiles were allowed to desorb for $3 \mathrm{~min}$ in the injector with a constant temperature of $250{ }^{\circ} \mathrm{C}$. The oven temperature was increased from $35^{\circ} \mathrm{C}$ to $250^{\circ} \mathrm{C}$ at a rate of $50{ }^{\circ} \mathrm{C} \cdot \mathrm{min}^{-1}$ and then held for $4 \mathrm{~min}$. Helium was used as carrier gas and the head pressure was maintained to give a constant flow rate of $1 \mathrm{~mL} \cdot \mathrm{min}^{-}$ 1 . Analysis was conducted using a Hewlett Packard wide bore capillary column $(30 \mathrm{~m}$ length $\times 0.25 \mathrm{~mm}$ i.d.) with a splitless injection. Volatiles were identified by analysis of fragmentation profiles using a Hewlett Packard 5971 MS detector combined with confirmatory library matches. Quantification of $\alpha$-farnesene was accomplished using the abundance of characteristic ion 93 and reported as units per kilogram fresh weight per min. A reading of 1000 in abundance was defined as one unit.

Because $\alpha$-farnesene is highly retained in fruit cuticle, undetectable $\alpha$-farnesene in the headspace using the SPME method may not be representative of its production at very low rates. Therefore, in fruit treated with oil-formulated Lovastatin, or whenever $\alpha$-farnesene was not detectable from the headspace using the SPME method, a confirmatory hexane extraction of fruit peel was used to measure $\alpha$-farnesene. Two discs of fruit peel were taken from each of the five fruit using a brass cork borer $2 \mathrm{~cm}$ in diameter. Discs were combined and extracted with $30 \mathrm{~mL}$ hexane for $30 \mathrm{~min}$. One microliter hexane extract was injected into the GC-MS for $\alpha$-farnesene measurement. Oven temperature was increased from $55^{\circ} \mathrm{C}$ to $280^{\circ} \mathrm{C}$ at a rate of $30^{\circ} \mathrm{C} \cdot \mathrm{min}^{-1}$ and held for $7 \mathrm{~min}$.

INTERNAL ETHYLENE MEASUREMENT. Internal ethylene was measured from 10 individual fruit from each replication using gas chromatography. A glass column $(610 \mathrm{~mm} \times 3.2 \mathrm{~mm}$ i.d. $)$ packed with Porapak Q (90 to 100 mesh) was used. Oven, injector, and flame ionization detector temperatures were 50,50 , and $200^{\circ} \mathrm{C}$, respectively. Gas flows for $\mathrm{N}_{2}$ carrier, $\mathrm{H}_{2}$, and air were 30,30 , and $300 \mathrm{ml} \cdot \mathrm{min}^{-1}$, respectively.

Statistical analysis. Data were subjected to analysis of variance (ANOVA) procedures using SAS statistical software (SAS Institute Inc., Cary, N.C.). In tables, means were separated using Duncan's new multiple range test at $P \leq 0.05$ when ANOVA indicated significance. In figures, means were compared using the least significant difference (LSD) procedures at $P$ $\leq 0.05$. Only results significant at $P \leq 0.05$ are discussed.

\section{Results}

EFFECTS OF LOVASTATIN ON INTERNAL ETHYLENE CONCENTRATION. Internal ethylene in control fruit was $<0.1 \mathrm{~mL} \cdot \mathrm{L}^{-1}$ at harvest and increased rapidly during $30 \mathrm{~d}$ storage at $20^{\circ} \mathrm{C}$ (Table 1$)$. Fruit treated with stripped corn oil alone reduced internal ethylene concentration during the first $18 \mathrm{~d}$ storage compared to the controls. Internal ethylene was higher in oil-treated fruit by the end of storage compared with control fruit. Internal ethylene in 
Lovastatin-treated fruit followed the same trend as in oil-treated fruit. Compared with the oil treatment, Lovastatin had no effect on internal ethylene concentration. When Lovastatin was applied as an emulsion, it did not reduce internal ethylene concentration.

EFFects of LOVASTATIN ON $\alpha$-FARNESENE PRODUCTION. Before the climacteric rise in ethylene, $\alpha$-farnesene was not detectable in the fruit (Table 1). It increased to a maximum around day 18 and then decreased slowly. Lovastatin at $0.625,1.25$ or $2.5 \mathrm{mmol} \cdot \mathrm{L}^{-1}$ inhibited $\alpha$-farnesene biosynthesis to very low levels during $30 \mathrm{~d}$ storage at $20^{\circ} \mathrm{C}$, as determined by headspace analysis and hexane extraction of fruit peels. Lovastatin at $0.25 \mathrm{mmol} \cdot \mathrm{L}^{-1}$ delayed $\alpha$ farnesene production for $12 \mathrm{~d}$ and reduced $\alpha$-farnesene synthesis thereafter. Stripped oil alone also delayed and reduced $\alpha$-farnesene production.

EFFECTS OF ETHEPHON TREATMENT ON ETHYLENE AND $\alpha$ FARNESENE PRODUCTION IN CONTROL AND LOVASTATIN-TREATED FRUIT. Ethephon treatment increased internal ethylene accumula- tion and $\alpha$-farnesene production in control fruit (Table 1). In Lovastatin-treated fruit, however, it increased internal ethylene concentration to the same level of controls, but did not induce $\alpha$ farnesene production.

EFFECT OF LOVASTATIN AND ETHEPHON ON INTERNAL ETHYLENE AND $\alpha$-FARNESENE PRODUCTION IN FRUIT STORED AT $0{ }^{\circ} \mathrm{C}$ FOR 30 DAYS. Both ethylene and $\alpha$-farnesene were detected in fruit after $30 \mathrm{~d}$ storage at $0{ }^{\circ} \mathrm{C}$ (Fig 1A). When these fruit were treated with Lovastatin and placed in a room with air circulation at $20^{\circ} \mathrm{C}, \alpha$ farnesene decreased rapidly. In fruit treated with $1.25 \mathrm{mmol} \cdot \mathrm{L}^{-1}$ Lovastatin, $\alpha$-farnesene was not detectable after $5 \mathrm{~d}$ and it remained undetectable thereafter by both head space and hexane extraction methods. Ethephon did not increase $\alpha$-farnesene production. In control fruit, $\alpha$-farnesene remained relatively constant. Ethephon treatment increased $\alpha$-farnesene production. During $20 \mathrm{~d}$ storage, there was no difference in internal ethylene concentration between Lovastatin-treated and control fruit. Ethe-

Table 1. Effects of Lovastatin treatments on internal ethylene concentration and $\alpha$-farnesene production in 'Golden Supreme' apples.

\begin{tabular}{|c|c|c|c|c|c|c|c|c|}
\hline \multirow[b]{2}{*}{ Formulation } & \multirow{2}{*}{$\begin{array}{l}\text { Lovastatin } \\
\left(\mathrm{mmol} \cdot \mathrm{L}^{-1}\right)\end{array}$} & \multirow{2}{*}{$\begin{array}{l}\text { Ethephon } \\
\left(\mathrm{mmol} \cdot \mathrm{L}^{-1}\right)\end{array}$} & \multicolumn{6}{|c|}{ Days at $20^{\circ} \mathrm{C}$} \\
\hline & & & 0 & 6 & 12 & 18 & 24 & 30 \\
\hline & \multicolumn{8}{|c|}{ Internal ethylene $\left(\mathrm{mL} \cdot \mathrm{L}^{-1}\right)$} \\
\hline \multirow[t]{5}{*}{ Oil } & 0 (blank) & 0 & 0.4 & $542 \mathrm{a}^{\mathrm{z}}$ & $696 a$ & $1280 \mathrm{a}$ & $832 \mathrm{a}$ & $766 \mathrm{~b}$ \\
\hline & 0 (oil) & 0 & 0.4 & $232 b$ & $153 \mathrm{~b}$ & $329 \mathrm{~b}$ & $720 \mathrm{a}$ & $1150 \mathrm{a}$ \\
\hline & 0.25 & 0 & 0.4 & $212 b$ & $129 \mathrm{~b}$ & $329 \mathrm{~b}$ & $875 a$ & $1080 \mathrm{a}$ \\
\hline & 1.25 & 0 & 0.4 & $117 \mathrm{~b}$ & $170 \mathrm{~b}$ & $324 b$ & $786 a$ & $1120 \mathrm{a}$ \\
\hline & 2.50 & 0 & 0.3 & $296 \mathrm{~b}$ & $144 \mathrm{~b}$ & $333 \mathrm{~b}$ & $779 \mathrm{a}$ & $1200 \mathrm{a}$ \\
\hline ANOVA $^{y}$ & & & NS & $*$ & $*$ & $*$ & $*$ & $*$ \\
\hline \multirow[t]{4}{*}{ Emulsion } & 0 & 0 & 0.3 & 619 & 862 & 1130 & 760 & 838 \\
\hline & 0.25 & 0 & 0.4 & 612 & 939 & 994 & 717 & 837 \\
\hline & 0.63 & 0 & 0.4 & 642 & 898 & 1110 & 673 & 950 \\
\hline & 1.25 & 0 & 0.3 & 747 & 1000 & 1120 & 849 & 966 \\
\hline ANOVA & & & NS & NS & NS & NS & NS & NS \\
\hline \multirow[t]{4}{*}{ Emulsion } & 0 & 1.4 & 0.4 & 1150 & 1840 & 1870 & 1030 & 925 \\
\hline & 0.25 & 1.4 & 0.4 & 1060 & 1690 & 1820 & 1230 & 767 \\
\hline & 0.63 & 1.4 & 0.3 & 1150 & 1720 & 2170 & 1080 & 1020 \\
\hline & 1.25 & 1.4 & 0.4 & 995 & 1770 & 1840 & 1100 & 977 \\
\hline ANOVA & & & NS & NS & NS & NS & NS & NS \\
\hline \multirow[t]{2}{*}{ Lovastatin vs. Lovastatin + ethephon } & & & NS & $*$ & $*$ & $*$ & $*$ & $*$ \\
\hline & \multicolumn{8}{|c|}{$\alpha$-Farnesene (units $/ \mathrm{kg} / \mathrm{min}$ ) } \\
\hline \multirow{5}{*}{ Oil } & 0 (blank) & 0 & 0 & $13.0 \mathrm{a}$ & $21.2 \mathrm{a}$ & $23.8 \mathrm{a}$ & $16.4 \mathrm{a}$ & $12.3 \mathrm{a}$ \\
\hline & 0 (oil) & 0 & 0 & $0.2 \mathrm{~b}$ & $1.8 \mathrm{~b}$ & $2.8 \mathrm{~b}$ & $5.0 \mathrm{~b}$ & $10.5 \mathrm{~b}$ \\
\hline & 0.25 & 0 & 0 & $0 \mathrm{c}$ & $0.1 \mathrm{c}$ & $2.6 \mathrm{~b}$ & $2.4 \mathrm{c}$ & $6.5 \mathrm{c}$ \\
\hline & 1.25 & 0 & 0 & $0 \mathrm{c}$ & $0 \mathrm{c}$ & $0.2 \mathrm{c}$ & $0.4 \mathrm{~d}$ & $0 \mathrm{~d}$ \\
\hline & 2.50 & 0 & 0 & $0 \mathrm{c}$ & $0 \mathrm{c}$ & $0.1 \mathrm{c}$ & $0.3 \mathrm{~d}$ & $0 \mathrm{~d}$ \\
\hline ANOVA & & & NS & $*$ & $*$ & $*$ & $*$ & $*$ \\
\hline \multirow[t]{4}{*}{ Emulsion } & 0 & 0 & 0 & $11.8 \mathrm{a}$ & $24.6 \mathrm{a}$ & $20.5 \mathrm{a}$ & $19.4 \mathrm{a}$ & $14.0 \mathrm{a}$ \\
\hline & 0.25 & 0 & 0 & $0.4 \mathrm{~b}$ & $0.6 \mathrm{~b}$ & $5.2 \mathrm{~b}$ & $9.5 \mathrm{~b}$ & $11.3 \mathrm{~b}$ \\
\hline & 0.63 & 0 & 0 & $0 \mathrm{~b}$ & $0.4 \mathrm{~b}$ & $0.9 \mathrm{c}$ & $1.8 \mathrm{c}$ & $0 \mathrm{c}$ \\
\hline & 1.25 & 0 & 0 & $0 \mathrm{~b}$ & $0 \mathrm{c}$ & $0.2 \mathrm{c}$ & $0.8 \mathrm{~d}$ & $0 \mathrm{c}$ \\
\hline ANOVA & & & NS & $*$ & $*$ & $*$ & $*$ & $*$ \\
\hline \multirow{4}{*}{ Emulsion } & 0 & 1.4 & 0 & $20.8 \mathrm{a}$ & $47.3 \mathrm{a}$ & $33.1 \mathrm{a}$ & $28.6 \mathrm{a}$ & $22.0 \mathrm{a}$ \\
\hline & 0.25 & 1.4 & 0 & $0.5 \mathrm{~b}$ & $0.7 \mathrm{~b}$ & $5.7 \mathrm{~b}$ & $11.8 \mathrm{~b}$ & $11.6 \mathrm{~b}$ \\
\hline & 0.63 & 1.4 & 0 & $0 \mathrm{c}$ & $0.6 \mathrm{bc}$ & $1.1 \mathrm{c}$ & $1.5 \mathrm{c}$ & $0 \mathrm{c}$ \\
\hline & 1.25 & 1.4 & 0 & $0 \mathrm{c}$ & $0.2 \mathrm{c}$ & $0.3 \mathrm{c}$ & $0.9 \mathrm{c}$ & $0 \mathrm{c}$ \\
\hline ANOVA & & & NS & $*$ & $*$ & $*$ & $*$ & $*$ \\
\hline Effect of ethephon in control fruit & & & NS & $*$ & $*$ & $*$ & $*$ & $*$ \\
\hline Effect of ethephon in Lovastatin-treated fruit & & & NS & NS & NS & NS & NS & NS \\
\hline
\end{tabular}

${ }^{\mathrm{z}}$ Mean separation in columns for a particular formulation or treatment by Duncan's new multiple range test, at $P \leq 0.05$.

Ns, ${ }^{*}$ nonsignificant or significant at $P \leq 0.05$, respectively. 

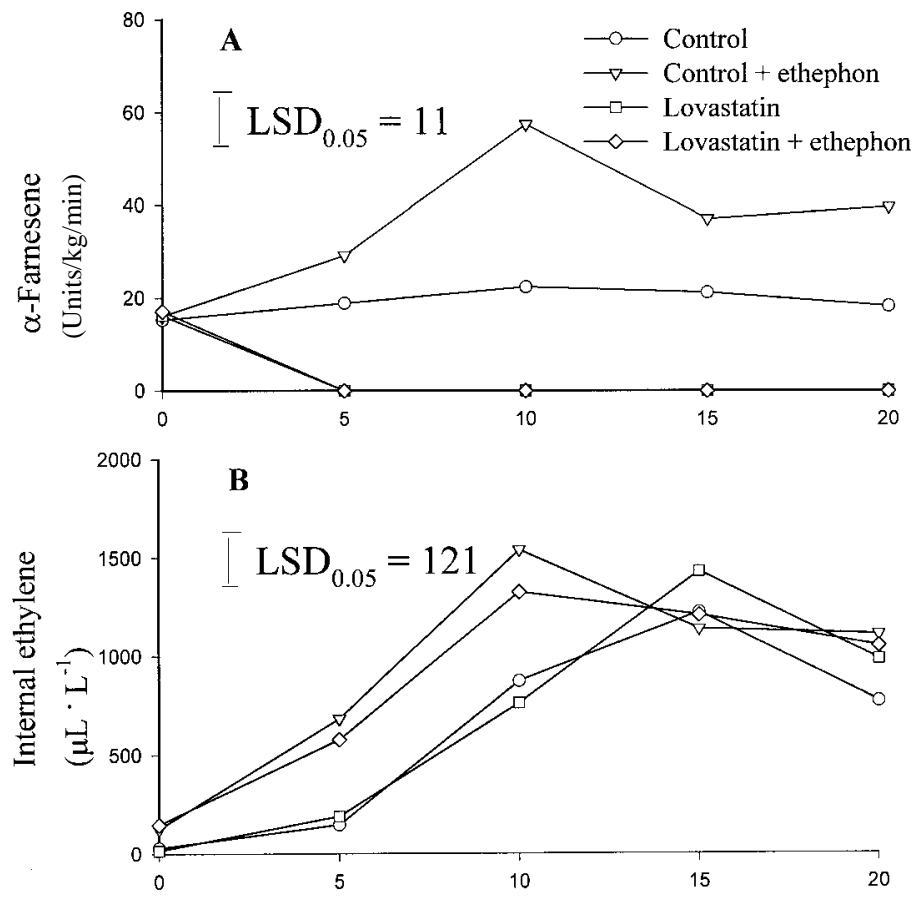

Days at $20^{\circ} \mathrm{C}$

Fig. 1. Effects of Lovastatin and ethephon treatments on (A) $\alpha$-farnesene biosynthesis and (B) internal ethylene in 'Golden Supreme' apples held at $20^{\circ} \mathrm{C}$ for $20 \mathrm{~d}$. Lovastatin $\left(1.25 \mathrm{mmol} \cdot \mathrm{L}^{-1}\right)$ and ethephon $\left(1.4 \mathrm{mmol} \cdot \mathrm{L}^{-1}\right)$ were applied to fruit that had been stored at $0{ }^{\circ} \mathrm{C}$ for $30 \mathrm{~d}$. Legend in $\mathbf{A}$ applies to both figures.

phon treatment increased internal ethylene concentration in both Lovastatin-treated fruit and control fruit to the similar level.

EFFECTS OF LOVASTATIN ON VOLATILE PRODUCTION. Eight major volatile peaks were identified in control fruit in addition to $\alpha$ farnesene (Table 2; Fig. 2). Most of them were $\mathrm{C}_{6}$ or $\mathrm{C}_{12}$ esters. The abundance of other individual volatiles was always smaller than $\alpha$-farnesene (Fig. 2). Lovastatin inhibited ester production in a dose-dependent manner.

EFFECTS OF LOVASTATIN TREATMENT ON CHANGE IN FRUIT COLOR. Lovastatin treatment did not affect fruit color compared with oil treatment (Table 3). However, all treatments including stripped oil inhibited color change from green to yellow compared with controls. When the emulsion formulation was used, the color readings were similar between the Lovastatin-treated fruit and the controls.

Table 2. Headspace volatile compounds from postclimacteric 'Golden Supreme' apples.

\begin{tabular}{llll}
\hline \hline $\begin{array}{l}\text { Peak } \\
\text { no. }\end{array}$ & $\begin{array}{l}\text { Retention } \\
\text { time } \\
(\mathrm{min})\end{array}$ & $\begin{array}{l}\text { Elucidated } \\
\text { s0can } \\
\text { no. }\end{array}$ & $\begin{array}{l}\text { Structure } \\
\text { of compound }\end{array}$ \\
\hline 1 & 5.35 & 53 & Ethyl butanoate \\
2 & 5.98 & 154 & Butyl butanoate \\
3 & 6.05 & 166 & Hexyl acetate \\
4 & 6.39 & 219 & Hexyl propanoate \\
5 & 6.74 & 275 & Butyl hexanoate \\
6 & 6.90 & 299 & Hexyl butyrate \\
7 & 6.94 & 307 & Methylbutyl hexanoate \\
8 & 7.35 & 373 & Hexyl hexanoate \\
9 & 7.73 & 1027 & $\alpha$-Farnesene \\
\hline
\end{tabular}

\section{Discussion}

'Golden Supreme' apples were selected for this study for two reasons. First, they are usually harvested 2 to 3 weeks before 'Golden Delicious' and experience a relatively rapid and clearly identifiable climacteric. We were interested primarily in the relationship between ethylene and $\alpha$-farnesene, and whether Lovastatin was effective in both pre- and postclimacteric tissue, and this cultivar afforded the opportunity to obtain results for possible subsequent experiments the same season. Second, previous experience with this cultivar indicated if fruit were harvested immature (often during the hottest weather) and held in regular storage beyond 4 months, scald developed. Thus, we knew we were working with a physiologically relevant cultivar. Although a greater understanding of the development of scald was the impetus behind the work, scald development was not measured in this study because treating sufficient fruit for scald evaluation after storage, without knowing whether the Lovastatin or our application methods were effective, was an imprudent use of a very costly, albeit gratis, compound.

The hypothesis that $\alpha$-farnesene accumulation in fruit cuticle is the primary factor leading to the development of scald in apples

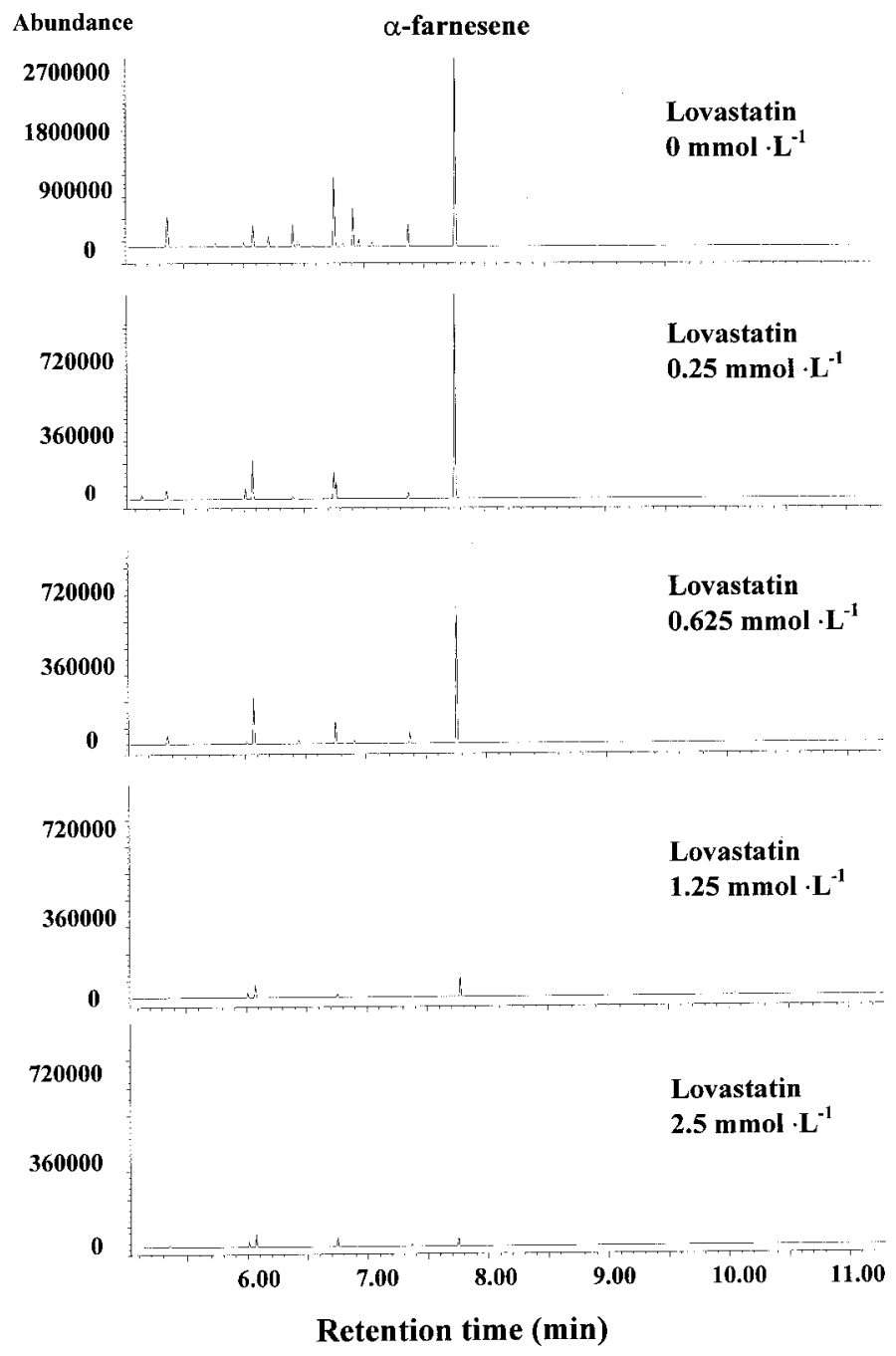

Fig. 2. Effects of Lovastatin concentrations on $\alpha$-farnesene and other volatile production in 'Golden Supreme' apples. Data were from fruit that were treated at harvest and stored at $20^{\circ} \mathrm{C}$ for $30 \mathrm{~d}$. 
Table 3. Effects of Lovastatin on color change in 'Golden Supreme' apples after $30 \mathrm{~d}$ at $20^{\circ} \mathrm{C}$.

\begin{tabular}{lccc}
\hline & & Color characteristic \\
\cline { 2 - 4 } Treatment & $\mathrm{L}^{*}$ & $\mathrm{C}^{*}$ & Oil formulation \\
\hline & & 47.9 & $79.9 \mathrm{a}$ \\
Untreated & $77.5 \mathrm{a}^{\mathrm{z}}$ & 47.3 & $69.6 \mathrm{~b}$ \\
Oil & $72.3 \mathrm{~b}$ & 48.0 & $68.6 \mathrm{~b}$ \\
Lovastatin $\left(0.25 \mathrm{mmol} \cdot \mathrm{L}^{-1}\right)$ & $72.7 \mathrm{~b}$ & 48.8 & $69.6 \mathrm{~b}$ \\
Lovastatin $\left(1.25 \mathrm{mmol} \cdot \mathrm{L}^{-1}\right)$ & $71.7 \mathrm{~b}$ & 47.8 & $70.6 \mathrm{~b}$ \\
Lovastatin $\left(2.5 \mathrm{mmol} \cdot \mathrm{L}^{-1}\right)$ & $72.6 \mathrm{~b}$ & $\mathrm{NS}$ & \\
ANOVA & $* *$ & Emulsion & \\
& & 47.3 & 79.0 \\
Lovastatin $\left(0 \mathrm{mmol} \cdot \mathrm{L}^{-1}\right)$ & 77.2 & 46.9 & 79.5 \\
Lovastatin $\left(0.25 \mathrm{mmol} \cdot \mathrm{L}^{-1)}\right.$ & 76.1 & 48.3 \\
Lovastatin $\left(0.625 \mathrm{mmol} \cdot \mathrm{L}^{-1}\right)$ & 77.9 & $\mathrm{NS}$ & 80.6 \\
Lovastatin $\left(1.25 \mathrm{mmol} \cdot \mathrm{L}^{-1}\right)$ & 79.1 & $\mathrm{NS}$ & $\mathrm{NS}$ \\
ANOVA & $\mathrm{NS}$ &
\end{tabular}

${ }^{\mathrm{z}}$ Mean separation in columns for a particular formulation by Duncan's new multiple range test at $P \leq 0.05$.

Ns, ${ }^{* *}$ Nonsignificant or significant at $P \leq 0.01$, respectively.

was proposed based on correlation analysis (Huelin and Murray, 1966), and most of the supporting studies were also conducted with correlation analysis (Barden and Bramlage, 1994; Huelin and Coggiola, 1970a, 1970b; Whitaker et al., 1997). The direct effect of $\alpha$-farnesene on scald development has not been proven conclusively. Our results demonstrated that Lovastatin inhibited $\alpha$-farnesene production without affecting ethylene synthesis in 'Golden Supreme' apples (Table 1). Inhibition of $\alpha$-farnesene synthesis by Lovastatin was concentration-dependent. Ethephon increased internal ethylene concentration but did not induce $\alpha$ farnesene synthesis in Lovastatin-treated fruit, both in preclimacteric and climacteric fruit. Compared with controls, Lovastatin treatment did not affect color changes of fruit (Table 3 ), indicating that ethylene action might not be affected. Therefore, we have established a method whereby the direct effect of $\alpha$ farnesene on scald development in apples can be assessed using Lovastatin treatment.

Among volatiles produced by control fruit, nine major compounds were identified with $\alpha$-farnesene being the most abundant. Except for $\alpha$-farnesene, all of the volatiles were esters, and were similar to those identified from 'Delicious', 'Empire', and 'Gala' apples (Paliyath et al., 1997). Lovastatin also reduced ester production during fruit ripening (Fig. 2), and this inhibition was dose-dependent. Structural analyses showed that the predominant esters were composed of C6 compounds, such as hexanol and hexanoic acid (Table 2). In plants, the $\mathrm{C} 6$ precursors are derived mainly through lipoxygenase activity. Oxidation of unsaturated fatty acids, such as linolenic acid and linoleic acid, releases hexanal. Conversion of hexanal to hexanol and hexanoic acid then provides substrates for volatile biosynthesis (Gardner, 1995). Ester synthesis in apple fruit is also reported to be regulated by ethylene (Fan et al., 1998) and inhibition of ethylene production by AVG reduces volatile production (Bangerth and Streif, 1987; Halder-Doll and Bangerth, 1987). Further study is required to determine how Lovastatin inhibited ester synthesis without inhibiting ethylene production during fruit ripening.

Another interesting result is that both internal ethylene concentration and $\alpha$-farnesene production were reduced by stripped oil treatment. Recent reports show that plant oils (Curry, 1999; Ju, Z., unpublished data; Scott et al., 1995) and components from plant oils such as neutral lipids (Ju, Z., unpublished data) and squalene (Curry, 1999) effectively reduce scald development in apples. However, their mechanism in protecting fruit from scald is not clear. One explanation is that these oils or components might form a film on the fruit surface and thus reduce oxidative pressure in fruit peel (Curry, 1999; McDonald et al., 1993). This is supported by reports that low oxygen storage inhibits ethylene and $\alpha$-farnesene synthesis (Chen et al., 1985; Mattheis et al., 1998; Whitaker et al., 1997), as well as by our data indicating that oil treatment reduces ethylene and $\alpha$-farnesene production (Table 1). Inhibition of ethylene synthesis by plant oils might delay fruit ripening as demonstrated by the fact that oil-treated fruit had much lower rate of color change from green to yellow compared with the controls.

In conclusion, Lovastatin provides a useful tool to study separately the effects of ethylene and $\alpha$-farnesene on scald development in apples. If Lovastatin proves effective in reducing scald, it will provide direct evidence that $\alpha$-farnesene is the primary initiator for scald development in apples. With this understanding, Lovastatin may lead to a more effective tool to control scald without reducing other fruit qualities. Alternatively, Lovastatin may fail to reduce scald although it inhibits $\alpha$-farnesene synthesis effectively, which would demonstrate that other scald development mechanisms might exist in apples.

\section{Literature Cited}

Alberts, A.W., J. Chen, G. Kuron, V. Hunt, J. Huff, C. Hoffman, J. Rothrock, M. Lopez, H. Joshua, E. Harris, A. Patchett, R. Monagan, S. Currie, E. Stapley, G. Albers-Schonberg, O. Hensens, J. Hirshfield, K. Hoogsteen, J. Liesch, and J. Springer. 1980. Mevinolin: A highly potent competitive inhibitor of hydroxymethylglutaryl-coenzyme A reductase and a cholesterol-lowering agent. Proc. Natl. Acad. Sci. USA 77:3957-3961.

Anet, E.F.L.J. 1969. Auto oxidation of $\alpha$-farnesene. Austral. J. Chem. 22:2403-2410.

Bach, T.J. 1995. Some new aspects of isoprenoid biosynthesis in plants. A review. Lipids 30:191-202.

Bach, T.J. and H.K. Lichtenthaler. 1983. Inhibition by mevinolin of plant growth, sterol formation and pigment accumulation. Physiol. Plant. 59:50-56.

Bangerth, F. and J. Streif. 1987. Effects of aminoethoxyvinylglycine and low pressure storage on the post-storage production of aroma volatiles by 'Golden Delicious' apples. J. Sci. Food Agr. 41:351-360.

Barden, C.L. and W.J. Bramlage. 1994. Relationships of antioxidants in apple peel to changes in $\alpha$-farnesene and conjugated trienes during 
storage, and to superficial scald development after storage. Postharvest Biol. Technol. 4:23-33.

Chappell, J. 1995. Biochemistry and molecular biology of the isoprenoid biosynthesis pathway in plants. Annu. Rev. Plant Physiol. Plant Mol. Biol. 46:521-547.

Chappell, J. and R. Nable. 1987. Induction of sesquiterpenoid biosynthesis in tobacco cell-suspension cultures by fungal elicitor. Plant Physiol. 85:469-473.

Chen, P.K., R.J. Varga, and Y.Q. Xiao. 1985. Inhibition of $\alpha$-farnesene biosynthesis and its oxidation in the peel tissue of ' $d$ 'Anjou' pears by low-O2/elevated-CO2 atmospheres. Postharvest Biol. Technol. 3:215223.

Curry, E.A. 1994. Preharvest applications of ethephon reduce superficial scald of 'Fuji' and 'Granny' apples in storage. J. Hort. Sci. 69:11111116.

Curry, E.A. 1999. Farnesene and squalene reduce scald in apples and pears. Acta Hort. (in press).

Du, Z. and W.J. Bramlage. 1994. Roles of ethylene in the development of superficial scald in 'Cortland' apples. J. Amer. Soc. Hort. Sci. 119:516-523.

Fan, X., J.P. Mattheis, and D. Buchanan. 1998. Continuous requirement of ethylene for apple fruit volatile synthesis. J. Agr. Food Chem. 46:1959-1963.

Gardner, H.W. 1995. Biological roles and biochemistry of the lipoxygenase pathway. HortScience 30:197-205.

Halder-Doll, H. and F. Bangerth. 1987. Inhibition of autocatalytic $\mathrm{C}_{2} \mathrm{H}_{4}-$ biosynthesis by AVG applications and consequences on the physiological behavior and quality of apple fruits in cool storage. Scientia Hort. 33:87-96.

Huelin, F.E. and I.M. Coggiola. 1970a. Superficial scald, a functional disorder of stored apples. V. Oxidation of $\alpha$-farnesene and its inhibition by diphenylamine. J. Sci. Food Agr. 21:44-48

Huelin, F.E. and I.M. Coggiola. 1970b. Superficial scald, a functional disorder of stored apples. VII. Effects of applied $\alpha$-farnesene, temperature, and diphenylamine on scald and the concentration on oxidation of $\alpha$-farnesene in the fruit. J. Sci. Food Agr. 21:584-589.

Huelin, F.E. and K.E. Murray. 1966. $\alpha$-Farnesene in the natural coating of apples. Nature (London) 210:1260-1261.

Ingle, M. and M.C. D'Souza. 1989. Physiology and control of superficial scald of apples: A review. HortScience 24:28-31.
Mattheis, J.P., D.A. Buchanan, and J.K. Fellman. 1998. Volatile compounds emitted by 'Gala' apples following dynamic atmosphere storage. J. Amer. Soc. Hort. Sci. 123:426-432.

McGuire, R.G. 1992. Reporting of objective color measurements. HortScience 27:1254-1255.

McDonald, R.E., T.G. McCollum, and H.E. Nordby. 1993. Temperature conditioning and surface treatments of grapefruit affect expression of chilling injury and gas diffusion. J. Amer. Soc. Hort. Sci. 118:490-496.

Meigh, D.F. and A.A.E. Filmer. 1969. Natural skin coating of the apple and its influence on scald in storage. III. $\alpha$-farnesene. J. Sci. Food Agr. 18:307-313.

Murray, K.E., F.E. Huelin, and J.B. Davenport. 1964. Occurrence of $\alpha-$ farnesene in the natural coating of apples. Nature (London) 204:80.

Paliyath, G., M.D. Whiting, M.A. Stasiak, D.P. Murr, and B.S. Clegg. 1997. Volatile production and fruit quality during development of superficial scald in Red Delicious apples. Food Res. Intl. 30:95-103. Rupasinghe, H.P.V., G. Paliyath, and D.P. Murr. 1998. Biosynthesis of $\alpha$-farnesene and its relation to superficial scald development in 'Delicious' apples. J. Amer. Soc. Hort. Sci. 123:882-886.

Rowan, D.D., J.M. Allen, S. Fielder, J.A. Spicer, and M.A. Brimble. 1995. Identification of conjugated triene oxidation products of $\alpha$ farnesene in apple skin. J. Agr. Food Chem. 43:2040-2045.

SAS Inst., Inc. 1985. SAS user's guide: Statistics, version 5 ed. SAS Inst., Inc., Cary, N.C.

Scott, K.J., C.M.C. Yuen, and G.H. Kim. 1995. Reduction of superficial scald of apples with vegetable oils. Postharvest Biol. Technol. 6:219223.

Song, J. and R.M. Beaudry. 1996. Rethinking apple scald: New hypothesis on the causal reason for the development of scald in apples. HortScience 31:605 (abstr.).

Sutherland, O.R.W., C.H. Wearing, and R.F.N. Hutchins. 1977. Production of $\alpha$-farnesene, an attractant and oviposition stimulant for codling moth, by developing fruit of ten varieties of apple. J. Chem. Ecol. 3:625-631.

Watkins, C.B., C.L. Barden, and W.J. Bramlage. 1993. Relationships among $\alpha$-farnesene, conjugated trienes and ethylene production with superficial scald development of apples. Acta Hort. 343:155-160.

Whitaker, B.D., T. Solomos, and D. Harrison. 1997. Quantification of $\alpha$ farnesene and its conjugated trienol oxidation products from apple peel by C18-HPLC with UV detection. J. Agr. Food Chem. 45:760-765. 